\title{
THERMAL CONDITIONS IN WARSHIPS REFITTING AT H.M. NAVAL BASE, SINGAPORE
}

BY

\author{
G. SOUTHWELL-SANDER \\ From the Royal Navy
}

(RECEIVED FOR PUBLICATION OCTOBER 20, 1953)

Numerous investigations have been carried out in recent years to determine the thermal environment in warships at sea in the tropics. As far as is known there has been no previous study of the thermal environment in which men work when a ship is refitting in a dockyard in the tropics. The aim of this investigation was to assess these conditions by measuring air temperatures in a wide variety of compartments in different classes of ships during a refit, and to relate the findings to the levels of warmth above which it is known that increasing numbers of men are likely to collapse or become inefficient.

Temperature recordings were made during July, August, and September, 1951, in an aircraft carrier repair ship, two cruisers, a frigate, and a submarine. They were in dry dock, except on one occasion when the ship was alongside. Thirty-five compartments in all were investigated. An important part of the work was to estimate the effect on the thermal environment of artificial ventilation or recirculation of air.

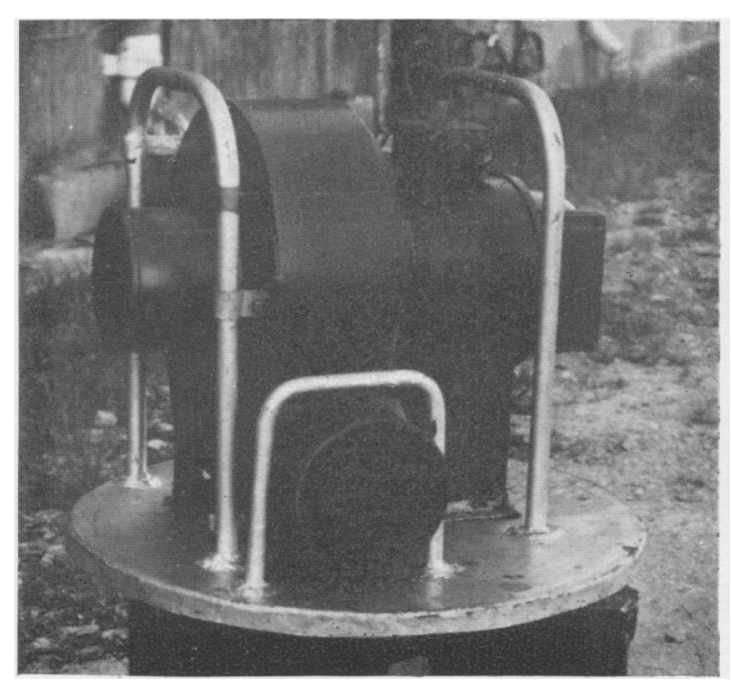

A

E
For the larger ships a refit usually lasts about eight to 10 weeks, of which five to seven weeks are spent in dry dock; for submarines a refit takes much longer. The conditions in a ship during a refit are abnormal, but vary slightly from ship to ship. While in dry dock, boilers are shut down and machinery is not running. As a result there is much less "wild heat" circulating within the ship than under normal conditions, but as power is not available there is usually no forced ventilation supply or exhaust. Dockside power is used for lighting and the recirculation of air between decks. On occasions a forced fresh air supply can be delivered through the punka louvre system to certain parts of the ship, but in many compartments the only method of circulating the air is by means of "doublebottom" fans, i.e., fans with hose extensions normally used to ventilate the space between the outer and inner plates below the water line (Fig. 1). As it is frequently not possible to arrange the intake from the outside air, the main effect is to increase

\footnotetext{
FIG. 1.-A is a 10-in. fan supplied with a 12-ft. length of canvas hose, and $B$ a 5 -in. fan supplied with an 8-ft. and 16-ft. length of canvas hose, showing air intake and outlet openings to which hoses can be attached.
}

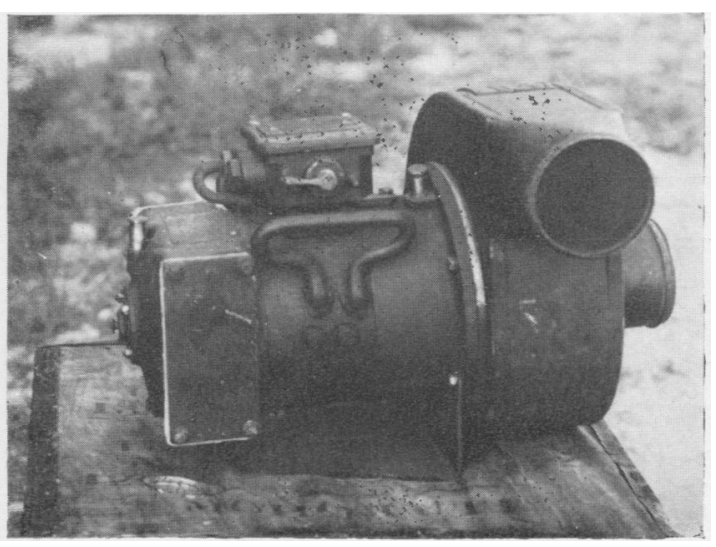

B 
the air movement within the ship without supplying fresh air.

Ships' staffs are employed as well as Asian dockyard workmen. A modified tropical routine is adopted for some of the ship's staff, especially the engineering and electrical branshes. The working hours were five a day although the actual times varied from ship to ship. In submarines, only Asian workmen are usually employed on manual work, with the ship's staff supervising. The men work stripped to the waist or wear overalls. The work is sometimes heavy and occasionally very unpleasant, as for example when water tanks are painted with bituminous compounds, when oil fuel tanks are cleaned, during welding processes when fumes may be strong, or in lagging operations when the atmosphere is dusty. All ships' companies are accommodated ashore during a refit.

\section{Methods}

The 35 compartments selected for this survey were nearly all between decks with no natural ventilation from the outside air, where conditions might be expected to be severe.

The methods for measuring environmental warmth were those described by Bedford (1946). External air temperatures were taken on the upper deck in the shade on each day before temperature measurements were made in compartments.

Dry-bulb, wet-bulb, and globe thermometer temperatures were observed in every compartment investigated. High temperature silvered kata thermometers (cooling range $130^{\circ}$ to $125^{\circ} \mathrm{F}$.) were used to measure the air speed. Effective temperatures were calculated from these observations. Observations were made in some compartments when double-bottom fans were in use, and in one small compartment when a table fan was used.

\section{Results}

The dry- and wet-bulb temperatures observed in the various compartments when the external temperatures ranged from $80^{\circ}$ to $92^{\circ} \mathrm{F}$. dry-bulb and $74^{\circ}$ to $81^{\circ} \mathrm{F}$. wet-bulb are summarized below :

\begin{tabular}{c|ccc}
\hline \multicolumn{2}{c}{ Dry-bulb Temperature } & \multicolumn{2}{c}{ Wet-bulb Temperature } \\
\hline Range $\left({ }^{\circ}\right.$ F.) & $\begin{array}{c}\text { No. of } \\
\text { Observations }\end{array}$ & Range $\left({ }^{\circ}\right.$ F.) & $\begin{array}{c}\text { No. of } \\
\text { Observations }\end{array}$ \\
\hline $84-87$ & 9 & $80-83$ & 18 \\
$87-90$ & 13 & $83-86$ & 11 \\
$90-93$ & 9 & $86-89$ & 4 \\
$93-96$ & 2 & $89-92$ & 1 \\
$96-97$ & 2 & $92-93$ & 1 \\
\hline
\end{tabular}

Most of the dry-bulb temperatures lay below $93^{\circ} \mathrm{F}$. and most of the wet-bulb temperatures below $86^{\circ} \mathrm{F}$.

Globe thermometer temperatures differed on only two occasions by more than $2^{\circ} \mathrm{F}$. from the dry-bulb temperatures recorded, namley, in a provision store and in one of the gun turrets on the upper deck, which was exposed directly to the sun's rays, showing that in this situation radiant heat may be a more important factor to consider. In the other compartments, which were between decks, radiant heat was not important.

Normally the air movement in the unventilated compartments was "still" (less than 10 feet per minute). When "double-bottom" fans were rigged, the air movement, but not the fresh air replenishment, was good, but then only when measurements were made in the direct line of the air flow from the fan. The air intake to the fan was usually from the compartment itself or an adjacent compartment, and so the fan merely recirculated air of the same temperature as the compartment air, and aided cooling of the body by increasing air movement. In only one of the 17 compartments investigated between decks was it possible to feed the fan from the outside fresh air.

Effective temperatures, calculated from basic and normal scales (as some men worked stripped to the waist and others wore overalls), were fairly high when there was no air movement, ranging from $81^{\circ}$ to $93^{\circ} \mathrm{F}$; the majority lay between $84^{\circ}$ and $87^{\circ} \mathrm{F}$.

Effective temperatures were lowered appreciably when fans were working and the air stream was directed on to the recording instrument. On these occasions the level of the basic effective temperature (for men stripped to the waist) was on the average $2^{\circ} \mathrm{F}$. below the corresponding normal effective temperature. Only a small distance from the line of the air stream, however, the air speed was very low.

\section{Discussion}

Although there have been many investigations in the past 50 years to determine the upper endurable limits of warmth for living and working conditions, it has not been possible as yet to state precisely under what conditions health will suffer, or to lay down exactly the acceptable environment for persons living and working in the tropics.

In the present investigation measurements were made only in compartments where the more severe conditions were likely to be encountered. No attempt was made to observe if any ill effects were experienced by the men, or if there was any lowering of their performance. The readings recorded will be discussed in the light of observations by other workers, who in the past have assessed the effects of hot environments on ability to work, efficiency, health, and comfort. 
Ability to Work.-Haldane (1905), from investigations in a mine and laboratories in Britain, believed that at $85^{\circ} \mathrm{F}$. wet-bulb temperature hard work was virtually impossible. Caplan and Lindsay (1946), however, investigating conditions in the Kolar gold fields in India, found that efficiency was hardly affected at this temperature. Caplan (1950) believes that $90^{\circ} \mathrm{F}$. is the crucial wet-bulb temperature at which temperature conditions become oppressive, fatigue is more marked, and the fall in efficiency is about $40 \%$. Above this temperature the danger of heat collapse increases. At a wet-bulb temperature of $93^{\circ} \mathrm{F}$. after the third hour of exposure, little useful work could be done and latent or obvious signs of heat collapse were likely to be observed. These conclusions, however, were based on southern Indian workmen acclimatized to working at wet-bulb temperatures of $93^{\circ} \mathrm{F}$.

Eichna, Ashe, Bean, and Shelley (1945), working at the Armoured Medical Research Laboratory, Fort Knox, Kentucky, give the following limiting wetbulb temperatures in relation to performance for men working in an air movement of about 200 feet per minute.

\begin{tabular}{l|c|c|c}
\hline & $\begin{array}{c}\text { Relatively } \\
\text { Easy }\end{array}$ & Difficult & Impossible \\
\cline { 2 - 3 } $\begin{array}{c}\text { Completely saturated } \\
\text { environment }\end{array}$ & $92.5^{\circ} \mathrm{F}$. & $94^{\circ} \mathrm{F}$. & $96^{\circ} \mathrm{F}$. \\
\hline
\end{tabular}

Thus there is a considerable difference between the definitions accepted by various workers for the limiting wet-bulb temperatures for different working conditions, but the range, $80^{\circ}$ to $93^{\circ} \mathrm{F}$., observed in compartments of ships refitting, when there was no air movement and with a high relative humidity, indicates that often the upper limits of tolerance were approached. The investigators, though only employed in the light activity of taking temperature readings over a short period of time, were drenched with sweat and found the conditions to be uncomfortable and exhausting.

The "effective temperature" is still recognized as the best available single index of the combined effects of air temperature, humidity, and air movement on sensations of individual comfort, though it may be misleading at very high levels of warmth. Yaglou (1926) found that the limiting conditions to which men could be exposed without sustaining ill effects lay between effective temperatures of $90^{\circ} \mathrm{F}$. at rest and $80^{\circ} \mathrm{F}$. doing heavy work; above $75^{\circ} \mathrm{F}$. he found that the output decreased gradually until $80^{\circ} \mathrm{F}$. was reached, when the fall was rapid. Bedford and Warner (1931) showed that the relative output of men filling tubs in coal mines in Britain was nearly halved when the average effective temperature was raised from $65 \cdot 8^{\circ}$ to $81 \cdot 8^{\circ} \mathrm{F}$. This finding can be compared with that of Caplan and Lindsay (1946) in the Kolar gold mines where efficiency remained at $100 \%$ when the effective temperature was $81 \cdot 8^{\circ} \mathrm{F}$.

It may be said, therefore, that under resting conditions men can tolerate an effective temperature of $90^{\circ} \mathrm{F}$. for several hours without serious ill effects, but if work is done this temperature threshold is quickly lowered.

Efficiency.-Houghten, Stacey, Urdahl, and Watt (1942) investigated the effects of warm conditions on the skill of unacclimatized young men and found that there was no adverse effect when the effective temperature was $73^{\circ}$ or $80^{\circ} \mathrm{F}$. but that it was reduced when it was raised to $87^{\circ} \mathrm{F}$. Mackworth $(1945,1946$, 1947) found that the critical level, during which skilled work is not so accurate for acclimatized men dressed in shorts, lay between effective temperatures of $83^{\circ}$ and $87.5^{\circ} \mathrm{F}$., but, as Ellis (1950) points out, these figures seem to refer to the normal effective temperature chart and not to the basic chart for men stripped to the waist, which would put the zone at a rather lower level. Mackworth's experiments actually showed that the critical region, above which men will not work so efficiently, whether work is mental or physical, lies between effective temperatures of $81^{\circ}$ and $86^{\circ} \mathrm{F}$.

Comfort.-Investigations recently undertaken from the Royal Naval Tropical Research Unit, Singapore, indicate that there is optimum comfort for men living in warships in the tropics and engaged in sedentary occupations when the effective temperature is between $73^{\circ}$ and $74^{\circ} \mathrm{F}$. The upper acceptable level of warmth under these conditions (when more than $80 \%$ of persons are reasonably comfortable, and less than $20 \%$ wet with perspiration) is an effective temperature of $78^{\circ} \mathrm{F}$. (Ellis, 1952).

Refitting Conditions. - In the compartments investigated the dry-and wet-bulb temperatures were all in the higher zones. The dry-bulb temperatures ranged from $84^{\circ}$ to $97^{\circ} \mathrm{F}$, and the wet-bulb temperatures between $80^{\circ}$ and $93^{\circ} \mathrm{F}$. At these temperatures the relative humidity of the atmosphere was usually over $75 \%$, and in a few instances approached $100 \%$. During the period these temperatures were taken the outside air temperatures varied between $80^{\circ}$ and $92^{\circ} \mathrm{F}$. dry-bulb and $74^{\circ}$ and $81^{\circ} \mathrm{F}$. wet-bulb. It is generally considered that the wet-bulb is more important than the dry-bulb temperature in assessing the effect of 
climate on man. These figures show the marked increase in the warmth of the internal air.

The effective temperatures observed lay at a fairly constant high level when there was no air movement, temperatures ranging from $81^{\circ}$ to $93^{\circ} \mathrm{F}$., the majority lying between $84^{\circ}$ and $87^{\circ} \mathrm{F}$.

In the light of the evidence referred to above it seems reasonable to conclude that the upper limits at which men can work efficiently are often approached in ships refitting in the tropics; the limiting conditions in which they are able to continue at hard work are reached at times, and the workers almost invariably experience thermal discomfort which is often severe. Working conditions during a refit, however, are often much worse than these bare figures indicate, because the work is arduous and unpleasant in other ways owing to fumes or dust. The average period in dry dock alone for larger ships is usually between six and seven weeks, with a total period of refit of about two months. Conditions are further aggravated when men have to work in overalls. In some ships the men can be said to be well acclimatized to a hot climate, but in others the only period for acclimatization to the hot, humid climate of Singapore is during the passage south from Japan.

Remedial Measures.-The beneficial effect of air movement on comfort and well-being in the higher zones of air temperature and when relative humidity is high is known to be of the utmost importance. Haldane (1905) found that in an air current of about 135 feet per minute, a wet-bulb temperature of about $85^{\circ} \mathrm{F}$. could be borne without an abnormal rise of body temperature. Dunham, Holling, Ladell, McArdle, Scott, Thompson, and Weiner, (1946) found that the limiting wet-bulb temperatures could be raised $2^{\circ}$ to $3^{\circ} \mathrm{F}$. if the speed of air movement increased from 10 to 200 feet per minute in hot humid conditions, but the effect of still air is more severe than the effective temperature scales indicate, and they suggest that the benefit gained by raising the general level of air movement above 300 feet per minute is exaggerated by the scales. An increase in air velocity from "still" conditions to about 200 to $\mathbf{4 0 0}$ feet per minute, with a "local cooling" effect, is required to produce a fall in effective temperature of $2^{\circ}$ to $3^{\circ} \mathrm{F}$., but even a few degrees' difference in effective temperature at the higher levels will produce a marked effect on comfort.

In ships refitting power is not usually available to provide ventilation by the punka louvre system. Compartments at the bottom of a ship are not normally provided with artificial ventilation though there may sometimes be a forced exhaust ; the only natural ventilation is by manholes, hatches, or doors to adjacent compartments. When men are working in these compartments the only means of air supply is usually by "double-bottom" fans driven by dockside power. In the lowest compartments it is not possible to provide hose extensions to the outside air, and so the air supply is merely recirculated air from adjacent compartments.

"Double-bottom" fans can be used either as supply or exhaust fans. Two sizes are normally used (10 in. and 5 in.), with speeds of 3,500 and 2,800 r.p.m. and weighing $110 \mathrm{lb}$. and $60 \mathrm{lb}$. respectively. There are numerous practical difficulties in rigging them to provide an air supply to remote compartments, and even with long hose extensions it is not always possible to reach some spaces. Adequate numbers of fans may not be available for one reason or another. Work may therefore have to be done in many compartments without any artificial air supply or air movement.

\section{Summary}

An investigation of the thermal environment of men working in the compartments of warships refitting at H.M. Naval Base, Singapore, was carried out during July, August, and September, 1951.

Thirty-five compartments in which conditions were expected to be severe were investigated in different classes of ships. These compartments, in most instances, had neither artificial nor natural ventilation.

When ships are refitting the only remedy for improving conditions is to recirculate the air in compartments between decks by means of " doublebottom " fans with hose extensions. It is rarely possible to arrange the air intake from the outside air.

When fans were not available working conditions were often found to be severe, with high wet-bulb temperatures and high effective temperatures. The efficiency of workers was then likely to be affected adversely, and in some compartments temperatures were in the zone where arduous work for prolonged periods is known to be impossible. The conditions were always uncomfortably warm. Working conditions are aggravated by the nature of the work which is often arduous and unpleasant and when men have to work in overalls.

Beneficial effects from increasing air movement, so reducing the effective temperature when a local cooling effect can be achieved, are suggested by the measurements made.

Radiant heat is not an important environmental 
factor in compartments between decks under refitting conditions.

I am greatly indebted to Surgeon Commander F. P. Ellis, Royal Navy, Director of the Royal Naval Tropical Research Unit, Singapore, for his advice in the preparation of this paper, to Sick Berth Chief Petty Officer W. Austin, A.R.S.I., for his assistance in recording temperatures, and to the Medical Director General of the Royal Navy for permission to publish.

\section{REFERENCES}

Bedford, T. (1946). Medical Research Council War Memorandum No. 17.

___, and Warner, C. G. (1931). J. industr. Hyg., 13, 252

Caplan, A. (1950). "Observations on the Effects of High Environmental Temperatures in Underground Workers on the Kolar mental Fiemperatures in Underground Workers on the Kolar Congress. Great Britain, July 1949, part 1, p. 398. (Paper No. D. 5). London.
Caplan, A., and Lindsay, J. K. (1946). An Experimental Investigation of the Effects of High Temperatures on the Efficiency of Workers in Deep Mines. Trans. Instn. Min. Metall., Lond., $56,163$.

Dunham W. Holling, H. E., Ladell, W. S. S. McArdle, B., Scott, J. W. Thompson, M. L., and Weiner, J.S. (1946). The Effects of Air Movement in Severe Heat. Report R.N.P. 46/316 to R.N. Air Movement in Severe Heat.
Personnel Research Committee.

Eichna, L. W., Ashe, W. F., Bean, W. B., and Shelley, W. B. (1945) J. industr. Hyg., 27, 59.

Ellis, F. P. (1950). Med. J. Malaya, 4, 175.

- (1952). J. Hyg., Camb., 50, 415.

Haldane, J. S. (1905). Ibid., 5, 494.

Houghten, F. C., Stacey, A. E., Urdahl, T. H., and Watt, R. M. (1942). Work Performance of Young Men in Comfortable and Hot Atmospheres, with Different Noise Levels. American Society of Heating and Ventilating Engineers Research Laboratory Report. U.S.N. Contract No. 66853. 20th March, 1942. Report. Wiltis (1950).

Mackworth, N. H. (1945). Effects of Heat and High Humidity on Pursuitmeter Scores. Report 45/199 to R.N. Personnel Research Committee.

-—, (1946). British Journal of Industrial Medicine, 3. 143. (1947). Brit. J. Psychol. (gen. sect.), 38, 90.

Yaglou, C. P. (1926). J. industr. Hyg., 8, 5. 